\title{
ANALISIS PUSHOVER UNTUK FONDASI TIANG KELOMPOK DENGAN MENGGUNAKAN TIANG PANCANG STEEL PIPE
}

\author{
Jimmi Lautan', Amelia Yuwono ${ }^{2}$ dan Giovanni Pranata ${ }^{3}$ \\ ${ }^{1}$ Program Studi Sarjana Teknik Sipil, Universitas Tarumanagara, Jl. Letjen S. Parman No.1 Jakarta \\ Email: jimmi.lautan@gmail.com \\ ${ }^{2}$ Program Studi Sarjana Teknik Sipil, Universitas Tarumanagara, Jl. Letjen S. Parman No.1 Jakarta \\ Email: amelia774@yahoo.com \\ ${ }^{3}$ Program Studi Sarjana Teknik Sipil, Universitas Tarumanagara, Jl. Letjen S. Parman No.1 Jakarta \\ Email: hendyw@ft.untar.ac.id
}

\begin{abstract}
ABSTRAK
Fondasi merupakan suatu konstruksi yang sangat penting terhadap suatu bangunan. Semua konstruksi yang direkayasa untuk bertumpu pada tanah harus didukung oleh suatu fondasi. Untuk mengetahui perilaku dan kinerja suatu tiang fondasi maka dengan menggunakan analisis pushover pada suatu kelompok tiang, perilaku tingkat kinerja suatu kelompok tiang dapat diketahui berdasarkan metode spektrum kapasitas yang diatur dalam ATC-40 dan Pushover Analysis of Underground Structutres. Hasil yang diperoleh bahwa konstruksi fondasi kelompok tiang yang diberi beban lateral berlebih memenuhi tingkat kinerja minimum yang ditetapkan.
\end{abstract}

Kata kunci: beban lateral berlebih, kelompok tiang, tingkat kinerja, metode spektrum kapasitas, Analisis Pushover

\section{PENDAHULUAN}

\section{Latar belakang}

Di zaman yang terus berkembang ini, banyak negara terus berupaya melakukan pembangunan infrastruktur di negaranya. Indonesia sebagai salah satu negara berkembang juga terus melakukan pembangunan guna mensejahterakan rakyat dan meningkatkan perekonomian negara. Setiap pembangunan infrastruktur tersebut pasti disertai konstruksi fondasi sebagai dasar pembangunan infrastruktur.

Bangunan konstruksi yang baik harus mengedepankan aspek kekuatan, keawetan, keindahan serta kesehatan. Dalam aspek kekuatan, suatu bangunan konstruksi harus mempunyai konstruksi yang kuat sehingga dapat melindungi penghuninya dari bahaya keruntuhan. Dalam aspek keawetan, suatu bangunan konstruksi diharapkan memiliki umur yang panjang. Dalam aspek keindahan, suatu bangunan konstruksi diharapkan tidak mengganggu kebersihan lingkungan sekitarnya. Untuk memenuhi segala aspek tersebut diperlukan adanya perencanaan yang baik dalam proses pembangunan suatu bangunan konstruksi. Salah satu perencanaan yang baik adalah dalam hal menganalisis fondasi.

Fondasi merupakan suatu konstruksi terpenting pada suatu bangunan. Semua konstruksi yang direkayasa untuk bertumpu pada tanah harus didukung oleh suatu fondasi. Fondasi berfungsi sebagai penahan seluruh beban yang berada di atasnya, gaya-gaya dari luar dan beratnya sendiri kemudian meneruskan beban kedalam tanah dan batuan yang terletak di bawahnya.

Secara garis besar, fondasi dibagi menjadi 2 klasifikasi yaitu fondasi dangkal dan fondasi dalam. Fondasi dangkal didefinisikan sebagai fondasi yang mendukung bebannya secara langsung dan beban yang diteruskan ke tanah tidak besar seperti fondasi telapak dan fondasi rakit. Fondasi dalam didefinisikan sebagai fondasi yang meneruskan beban bangunan ke lapisan tanah keras yang lebih dalam sampai didapat jenis tanah yang mampu mendukung beban struktur bangunan seperti fondasi tiang pancang dan fondasi bored pile.

Dengan kemajuan teknologi dan ilmu pengetahuan, analisis fondasi memiliki berbagai analisis, analisis fondasi juga menjadi mudah dengan menggunakan program yang ada. Salah satunya adalah analisis pushover.

Karena adanya perubahan dari SNI 1726:2002 menjadi SNI 1726:2012 maka ada beban gempa yang lebih besar dari SNI sebelumnya untuk beberapa wilayah Indonesia. Oleh karena itu dilakukan penelitian bagaimana perilaku fondasi tiang kelompok jika mengalami beban lateral berlebih, untuk mensimulasikan peningkatan beban gempa pada SNI 1726:2012. 


\section{Identifikasi masalah}

Penelitian akan meneliti tentang perilaku tiang kelompok terhadap gaya gempa yang diberikan dengan analisis pushover menggunakan program GROUP.

\section{Batasan masalah}

Agar penelitian ini terfokus pada 1 masalah yang spesifik, batasan-batasan masalahnya adalah :

1. Analisis pushover yang dilakukan menggunakan program GROUP sebagai bantuan untuk menganalisis tiang kelompok.

2. Tiang yang digunakan untuk analisis adalah steel pipe. Steel pipe yang digunakan berdiameter 500mm dengan tebal $10 \mathrm{~mm}, 600 \mathrm{~mm}$ dengan tebal $10 \mathrm{~mm}, 700 \mathrm{~mm}$ dengan tebal $10 \mathrm{~mm}, 800 \mathrm{~mm}$ dengan tebal 20mm,900mm dengan tebal $20 \mathrm{~mm}$.

3. Tiang kelompok yang dianalisis berjumlah 4 tiang, 5tiang dan 6 tiang kelompok.

4. Tiang kelompok dianalisis berdasarkan elastic dan non elastic.

5. Jenis tanah yang digunakan adalah tanah lunak.

\section{Rumusan masalah}

1. Bagaimana perilaku steel pipe yang dianalisis dengan analisis pushover menggunakan program GROUP terhadap tanah lunak?

2. Bagaimana tingkat kinerja pondasi kelompok yang menggunakan steel pipe terhadap beban lateral yang diberikan?

3. Bagaimana jumlah tiang pada tiang kelompok mempengaruhi perilaku tiang dengan beban lateral yang diberikan?

4. Bagaimana dimensi tiang mempengaruhi perilaku tiang kelompok saat di berikan beban lateral?

\section{Tujuan penelitian}

Tujuan dari penelitian ini adalah:

1. Mengetahui perilaku tiang kelompok yang menggunakan steel pipe dengan analisis pushover.

2. Mengetahui tingkat kinerja tiang kelompok yang menggunakan steel pipe melalui analisis pushover menurut peraturan ATC-40 dan pushover analysis of underground structures.

3. Mengetahui perbandingan beban lateral yang mampu diterima tiang kelompok elastic dan non elastic

\section{DASAR TEORI}

\section{Fondasi Tiang Pancang}

Fondasi adalah konstruksi struktur bawah bangunan yang langsung berhubungan dengan tanah, berfungsi sebagai penahan seluruh beban yang berada di atasnya, gaya-gaya dari luar dan beratnya sendiri kemudian meneruskan beban kedalam tanah dan batuan yang terletak di bawahnya.

Fondasi tiang adalah fondasi yang mampu menahan gaya orthogonal ke sumbu tiang dengan jalan menyerap lenturan. Fondasi tiang dibuat menjadi kesatuan yang monolit dengan menyatukan pangkal tiang yang terdapat di bawah konstruksi (Ir. Suryono Sosrodarsono, Kazuto Nakazawa, 2000).

Salah satu jenis Fondasi tiang menggunakan tiang pancang. Tiang pancang seringkali digunakan untuk mengontrol pergerakan tanah (seperti longsoran tanah). Para pembaca sepatutnya melihat bahwa tiang-tiang listrik dan banyak tiang tanda yang berada di luar dapat ditinjau sebagai tiang pancang yang tertanam sebagian dan yang terpengaruh beban-beban lateral.

\section{Tiang Pancang Baja}

Tiang pancang baja ini biasanya berbentuk $\mathrm{H}$ yang digiling atau merupakan tiang pancang pipa. Balok yang mempunyai flens lebar (wide-flange beam) atau balok-I dapat juga di gunakan tapi bentuk $\mathrm{H}$ khususnya dibuat sebanding untuk menahan tegangan pancangan yang keras yang mungkin dialami oleh tiang pancang tersebut. Dalam tiang pancang $\mathrm{H}$ flens dan badan mempunyai tebal yang sama. Bentuk WF yang standard dan bentuk $\mathrm{H}$ biasanya mempunyai badan yang lebih tipis dari flens.

Tiang pancang $\mathrm{H}$ adalah tiang pancang yang memiliki perpindahan volume yang kecil karena penampangnya tidak terlalu besar. Suatu sumbat cenderung terbentuk di antara flens-flens pada kedalaman yang lebih besar, meskipun demikian beberapa meter bagian dasarnya dapat mencetak kembali tanah sebesar volume sumbat. Sebuah pipa yang ujungnya terbuka juga dianggap sebuah pipa yang memiliki perpindahan volume yang kecil, meskipun demikian, suatu sumbat juga terbentuk dibagian dalamnya dengan kedalaman satu meter atau lebih dibawah level permukaan. 
Tiang pancang $\mathrm{H}$ mempunyai suatu keuntungan kekakuan yang memadai yang mana tiang $\mathrm{H}$ ini akan memecah bongkah-bongkah batu kecil atau memindahkannya ke satu sisi.

Pipa pancang baja merupakan salah satu bahan konstruksi yang paling sering digunakan untuk membuat jembatan. Meskipun demikian, tidak sedikit bangunan lain yang mengguankan pipa pancang baja sebagai material pondasinya, seperti misalnya bangunan pabrik, hotel, apartemen, serta bangunan bertingkat lainnya.

Pipa pancang baja dikenal begitu kuat sehingga mampu menyangga beban dengan bobot yang sangat besar. Jenis material ini biasa digunakan sebagai pondasi bangunan yang berada di kawasan berair atau wilayah dengan struktur tanah rapuh. Dengan pipa pancang baja, bangunan bisa berdiri kokoh karena ujung tiang bawahnya sudah bersandar pada lapisan tanah keras di bagian dalam bumi.

\section{Kinerja Struktur}

Kinerja struktur adalah tingkat performa suatu struktur dengan melihat tingkat kerusakannya saat terkena gempa rencana dengan periode ulang tertentu. Oleh karena itu, kinerja struktur erat kaitannya dengan biaya perbaikan terhadap bangunan tersebut. Semakin baik tingkat kinerja suatu struktur, maka semakin sedikit biaya perbaikan yang perlu dikeluarkan saat gempa rencana terjadi.

Dalam desain struktur berbasis kinerja, kinerja struktur didesain sesuai dengan fungsi bangunan tersebut dengan mempertimbangkan faktor ekonomis terhadap perbaikan bangunan saat terjadi gempa, tanpa mengesampingkan keselamatan pengguna bangunan itu sendiri.

\section{Kinerja Struktur Metode $A T C-40$}

Respons bangunan terhadap gerakan tanah saat terjadi gempa menyebabkan perpindahan lateral dan deformasi pada setiap elemen struktur. Pada respons awal, deformasi elemen akan bersifat elastis (linier) sehingga tidak ada kerusakan yang terjadi. Pada respons struktur yang lebih tinggi, deformasi elemen akan melebihi kapasitas linier elastis dan bangunan mulai mengalami kerusakan. Untuk memberikan kinerja struktur yang baik, bangunan harus memiliki sistem penahan gaya lateral yang lengkap agar deformasi lateral akibat gempa dapat dibatasi dan target kinerja yang diinginkan dapat tercapai. Faktor-faktor dasar yang mempengaruhi kemampuan sistem penahan gaya lateral untuk melakukan hal tersebut meliputi massa bangunan, kekakuan, redaman, dan konfigurasi: kapasitas deformasi pada elemen, kekuatan dan karakteristik gerakan tanah.

\section{Pushover analysis of underground structures}

Selain ATC-40 batasan yang harus dicek adalah untuk underground structures.Dimana performance point yang didapat dibagi dengan titik displacement $0 \mathrm{~m}$ sehingga mendapatkan pile drift ratio.

\section{METODOLOGI PENELITIAN}

\section{Metode pengumpulan data}

Data-data yang akan digunakan dalam penelitian ini adalah data tanah dan data steel pipe. Data tanah didapat dari proyek dapenbi daerah Jakarta Selatan dan data steel pipe didapat dari NIPPON STEEL \& SUMIMOTO METAL.

\section{Metode analisis data}

Analisis akan dilakukan dengan analisa pushover pada tiang kelompok yang menggunakan steel pipe. Hasil analisis berupa perilaku tiang yang telah diberi gaya lateral berlebih sesuai SNI 1726:2012. Akan dilakukan analisa lateral dengan kondisi tiang kelompok elastic dan non elastic.

Data yang keluar dari program GROUP berupa displacement tiap tiang untuk tiap load yang akan dianalisis dan diolah lagi dan dicek terhadap ATC-40 dan Pushover analysis of underground structures. 


\section{ANALISIS DATA}

Tabel 1 Tabel hasil analisis kelompok tiang berjumlah 4 tiang

\begin{tabular}{|c|c|c|c|c|c|c|c|c|}
\hline TIPE & $\begin{array}{l}\text { Uhuran } \\
\text { (mm) }\end{array}$ & tebal $(\mathrm{mm})$ & $\begin{array}{l}\text { Load } \\
\text { maksimum }(\mathrm{aN})\end{array}$ & Titik Displacement $0(\mathrm{~m})$ & Performance Point & $\begin{array}{c}\begin{array}{c}\text { Pile drift } \\
\text { ratio }\end{array} \\
\end{array}$ & Kategori & Kesimpulan \\
\hline \multirow{4}{*}{$\begin{array}{c}\text { Non } \\
\text { Elastic }\end{array}$} & \multirow{4}{*}{500} & \multirow[b]{2}{*}{10} & \multirow[b]{2}{*}{550} & & & & ATC- $400,01-0,02$ & Damage control \\
\hline & & & & 7 & 0.08 & 0.011428571 & $\begin{array}{l}\text { Sci Ching Tech Sci } \\
<1,5 \%\end{array}$ & Life gafe-Damage state \\
\hline & & \multirow{2}{*}{10} & \multirow{2}{*}{1300} & & & & ATC-40 0,01 & Immediate Occupancy \\
\hline & & & & 13 & 004 & 0003076023 & Sci China Tech Sci & Damage control \\
\hline \multirow{5}{*}{$\begin{array}{c}\text { Non } \\
\text { Elastic }\end{array}$} & \multirow{5}{*}{600} & \multirow{3}{*}{10} & \multirow{3}{*}{740} & & & & ATC- $400,01-0,02$ & Damage control \\
\hline & & & & 0 & 01 & 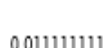 & Sci China Tech Sci & Lifo gafe-Domage atsta \\
\hline & & & & 9 & 0.1 & & & Lire garte-D mage gerese \\
\hline & & \multirow{2}{*}{10} & \multirow{2}{*}{1600} & & & & ATC-40 0,01 & Immediate Occupancy \\
\hline & & & & 15 & 0.0458 & 0.003053333 & $<0,5 \%$ & Damage control \\
\hline \multirow{5}{*}{$\begin{array}{c}\text { Non } \\
\text { Elastic }\end{array}$} & \multirow{5}{*}{700} & \multirow{3}{*}{10} & \multirow{3}{*}{970} & & & & ATC- 400,01 & Immediate Occupancy \\
\hline & & & & 0 & & 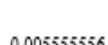 & Sci China Tech Sci & Jifoca D Done \\
\hline & & & & 9 & 0.05 & 0.00232323236 & $<1,5 \%$ & Lire garte-D manage trate \\
\hline & & \multirow{2}{*}{10} & \multirow{2}{*}{2000} & & & & ATC-40 0,01 & \\
\hline & & & & 16 & 0.04 & 0.0025 & $\begin{array}{l}\text { Sclanan Iech Scl } \\
<0,5 \%\end{array}$ & Damage control \\
\hline \multirow{5}{*}{$\begin{array}{c}\text { Non } \\
\text { Elastic }\end{array}$} & \multirow{6}{*}{800} & \multirow{3}{*}{20} & \multirow{3}{*}{1500} & & & & ATC- 400,01 & Immediate Occupancy \\
\hline & & & & & & & 5ci china Tech Sci & \\
\hline & & & & 14 & 0.13 & 0.009285714 & $<1,5 \%$ & Life gafe-Damage gtate \\
\hline & & \multirow{3}{*}{20} & \multirow{3}{*}{3600} & & & & ATC-40 0,01 & Immediate Occupancy \\
\hline & & & & & & & Sci China Tech Sci & \\
\hline Elastic & & & & 21 & 0.09 & 0.004285714 & $<0,5 \%$ & Damage control \\
\hline \multirow{4}{*}{$\begin{array}{c}\text { Non } \\
\text { Elastic }\end{array}$} & \multirow{4}{*}{900} & \multirow[b]{2}{*}{20} & \multirow[b]{2}{*}{1800} & & & & ATC-400,01 & Immediate Occupancy \\
\hline & & & & 15 & 0,07 & 0004666667 & Sci China Tech Sci & Damage control \\
\hline & & \multirow[b]{2}{*}{20} & \multirow[b]{2}{*}{3900} & & & & ATC-400.01 & Immediate Occupancy \\
\hline & & & & 2 & 008 & 0003636764 & Sci China Tech Sci & Damage control \\
\hline
\end{tabular}

Tabel 2 Tabel hasil analisis kelompok tiang berjumlah 5 tiang

\begin{tabular}{|c|c|c|c|c|c|c|c|c|}
\hline TIPE & Ukuran (mm) & $\begin{array}{l}\text { tebal } \\
(\mathrm{mm})\end{array}$ & Load maksimum & $\begin{array}{l}\text { Titik Displacement } 0 \\
(\mathrm{~m})\end{array}$ & Performance Point & Pile drift ratio & Kategori & Kesimpulan \\
\hline $\begin{array}{l}\text { Non } \\
\text { Elastic }\end{array}$ & \multirow{2}{*}{500} & 10 & 730 & 6 & 0.05 & 0.008333333 & $\begin{array}{l}\text { ATC-40 0,01 } \\
\text { Sci China Tech Sci } \\
<1,5 \%\end{array}$ & $\begin{array}{l}\text { Immediate Occupancy } \\
\text { Life safe-Damage state }\end{array}$ \\
\hline Elastic & & 10 & 1700 & 12 & 0.04 & 0.003333333 & $\begin{array}{l}\text { ATC-40 0,01 } \\
\text { Sci China Tech Sci } \\
<0,5 \%\end{array}$ & $\begin{array}{l}\text { Immediate Occupancy } \\
\text { Damage Control }\end{array}$ \\
\hline $\begin{array}{c}\text { Non } \\
\text { Elastic }\end{array}$ & \multirow{2}{*}{600} & 10 & 900 & 7 & 0.04 & 0.005714286 & $\begin{array}{l}\text { ATC-40 0,01 } \\
\text { Sci China Tech Sci } \\
\leq 1,5 \%\end{array}$ & $\begin{array}{l}\text { Immediate Occupancy } \\
\text { Life safe-Damage state }\end{array}$ \\
\hline Elastic & & 10 & 1800 & 13 & 0.04 & 0.003076923 & $\begin{array}{l}\text { ATC-40 0, } 01 \\
\text { Sci China Tech Sci } \\
<0,5 \%\end{array}$ & $\begin{array}{l}\text { Immediate Occupancy } \\
\text { Damage Control }\end{array}$ \\
\hline $\begin{array}{l}\text { Non } \\
\text { Elastic }\end{array}$ & \multirow{2}{*}{700} & 10 & 1400 & 9 & 0.05 & 0.0055555556 & $\begin{array}{l}\text { ATC-40 0,01 } \\
\text { Sci China Tech Sci } \\
<1,5 \%\end{array}$ & $\begin{array}{l}\text { Immediate Occupancy } \\
\text { Life safe-Damage state }\end{array}$ \\
\hline Elastic & & 10 & 2600 & 15 & 0.03 & 0.002 & $\begin{array}{l}\text { ATC-40 0,01 } \\
\text { Sci China Tech Sci } \\
<0,5 \%\end{array}$ & $\begin{array}{l}\text { Immediate Occupancy } \\
\text { Damage Control }\end{array}$ \\
\hline $\begin{array}{l}\text { Non } \\
\text { Elastic }\end{array}$ & \multirow{2}{*}{800} & 20 & 1900 & 11 & 0.11 & 0.01 & $\begin{array}{l}\text { ATC-40 0,01 } \\
\text { Sci China Tech Sci } \\
<1,5 \%\end{array}$ & $\begin{array}{l}\text { Immediate Occupancy } \\
\text { Life safe-Damage state }\end{array}$ \\
\hline Elastic & & 20 & 4100 & 18 & 0.06 & 0.003333333 & $\begin{array}{l}\text { ATC-40 0,01 } \\
\text { Sci China Tech Sci } \\
<0,5 \%\end{array}$ & $\begin{array}{l}\text { Immediate Occupancy } \\
\text { Damage Control }\end{array}$ \\
\hline $\begin{array}{c}\text { Non } \\
\text { Elastic }\end{array}$ & \multirow{2}{*}{900} & 20 & 2300 & 11 & 0.06 & 0.005454545 & $\begin{array}{l}\text { ATC-40 0,01 } \\
\text { Sci China Tech Sci } \\
<1,5 \%\end{array}$ & $\begin{array}{l}\text { Immediate Occupancy } \\
\text { Life safe-Damage state }\end{array}$ \\
\hline Elastic & & 20 & 5500 & 22 & 0.06 & 0.002727273 & $\begin{array}{l}\text { ATC-40 0,01 } \\
\text { Sci China Tech Sci } \\
<0,5 \%\end{array}$ & Immediate Occupancy \\
\hline
\end{tabular}


Tabel 3 Tabel hasil analisis kelompok tiang berjumlah 6 tiang

\begin{tabular}{|c|c|c|c|c|c|c|c|c|}
\hline TIPE & $\begin{array}{c}\text { Ukuran } \\
(\mathrm{mm})\end{array}$ & $\begin{array}{l}\text { tebal } \\
(\mathrm{mm}) \\
\end{array}$ & Load Maksimum & $\begin{array}{l}\text { Titik Displacement } 0 \\
\text { (m) }\end{array}$ & Performance Point & Pile drift ratio & Kategori & Kesimpulan \\
\hline \multirow[b]{2}{*}{$\begin{array}{c}\text { Non } \\
\text { Elastic }\end{array}$} & \multirow{4}{*}{500} & \multirow[b]{2}{*}{10} & \multirow[b]{2}{*}{880} & & & & \multirow{2}{*}{$\begin{array}{l}\text { ATC-40 0,01 } \\
\text { Sci China Tech Sci } \\
<0,5 \%\end{array}$} & Immediate Occupancy \\
\hline & & & & 7 & 0.02 & 0.002857143 & & Damage Control \\
\hline \multirow{2}{*}{ Elastic } & & \multirow[b]{2}{*}{10} & \multirow[b]{2}{*}{2000} & & & & ATC-40 0,01 & Immediate Occupancy \\
\hline & & & & 0 & 004 & OhOA444444 & Sci China Tech Sci & Damage Control \\
\hline \multirow{3}{*}{$\begin{array}{l}\text { Non } \\
\text { Elastic }\end{array}$} & \multirow{6}{*}{600} & \multirow{3}{*}{10} & \multirow{3}{*}{1000} & & & & ATC-40 0,01 & Immediate Occupancy \\
\hline & & & & & & & Sci China Tech Sci & \\
\hline & & & & 9 & 0.08 & 0.008888889 & $<1,5 \%$ & Life safe-Damage state \\
\hline \multirow[b]{3}{*}{ Elastic } & & \multirow{3}{*}{10} & \multirow{3}{*}{2100} & & & & ATC-40 0,01 & Immediate Occupancy \\
\hline & & & & & & & Sci China Tech Sci & \\
\hline & & & & 14 & 0.0458 & 0.003271429 & $<0,5 \%$ & Damage Control \\
\hline \multirow{3}{*}{$\begin{array}{c}\text { Non } \\
\text { Elastic }\end{array}$} & \multirow{6}{*}{700} & \multirow{3}{*}{10} & \multirow{3}{*}{1400} & & & & ATC- 400,01 & Immediate Occupancy \\
\hline & & & & & & & Sci China Tech Sci & \\
\hline & & & & 9 & 0.046 & 0.005111111 & $<1,5 \%$ & Immediate Occupancy \\
\hline \multirow[b]{3}{*}{ Elastic } & & \multirow{3}{*}{10} & \multirow{3}{*}{2600} & & & & ATC- 400,01 & Immediate Occupancy \\
\hline & & & & & & & Sci China Tech Sci & \\
\hline & & & & 14 & 0.0458 & 0.003271429 & $<0,5 \%$ & Damage Control \\
\hline \multirow{3}{*}{$\begin{array}{c}\text { Non } \\
\text { Elastic }\end{array}$} & \multirow{6}{*}{800} & \multirow{3}{*}{20} & \multirow{3}{*}{2200} & & & & ATC-40 0,01 & Immediate Occupancy \\
\hline & & & & & & & Sci China Tech Sci & \\
\hline & & & & 11 & 0.09 & 0.008181818 & $<1,5 \%$ & Life safe-Damage state \\
\hline \multirow[b]{3}{*}{ Elastic } & & \multirow{3}{*}{20} & \multirow{3}{*}{4400} & & & & ATC- $-400,01$ & Immediate Occupancy \\
\hline & & & & & & & Sci China Tech Sci & \\
\hline & & & & 20 & 0.08 & 0.004 & $<0,5 \%$ & Damage Control \\
\hline \multirow{5}{*}{$\begin{array}{c}\text { Non } \\
\text { Elastic }\end{array}$} & & & & & & & ATC-40 0,01 & Immediate Occupancy \\
\hline & & 20 & 2600 & & & & Sci China Tech Sci & \\
\hline & 000 & & & 14 & 0.1 & 0.007142857 & $<1,5 \%$ & Life safe-Damage state \\
\hline & & & & & & & ATC-40 0,01 & Immediate Occupancy \\
\hline & & 20 & 5900 & & & & Sci China Tech Sci & \\
\hline Elastic & & & & 22 & 0.07 & 0.003181818 & $<0,5 \%$ & Damage Control \\
\hline
\end{tabular}

Spektrum kapasitas untuk 4 tiang non elastic

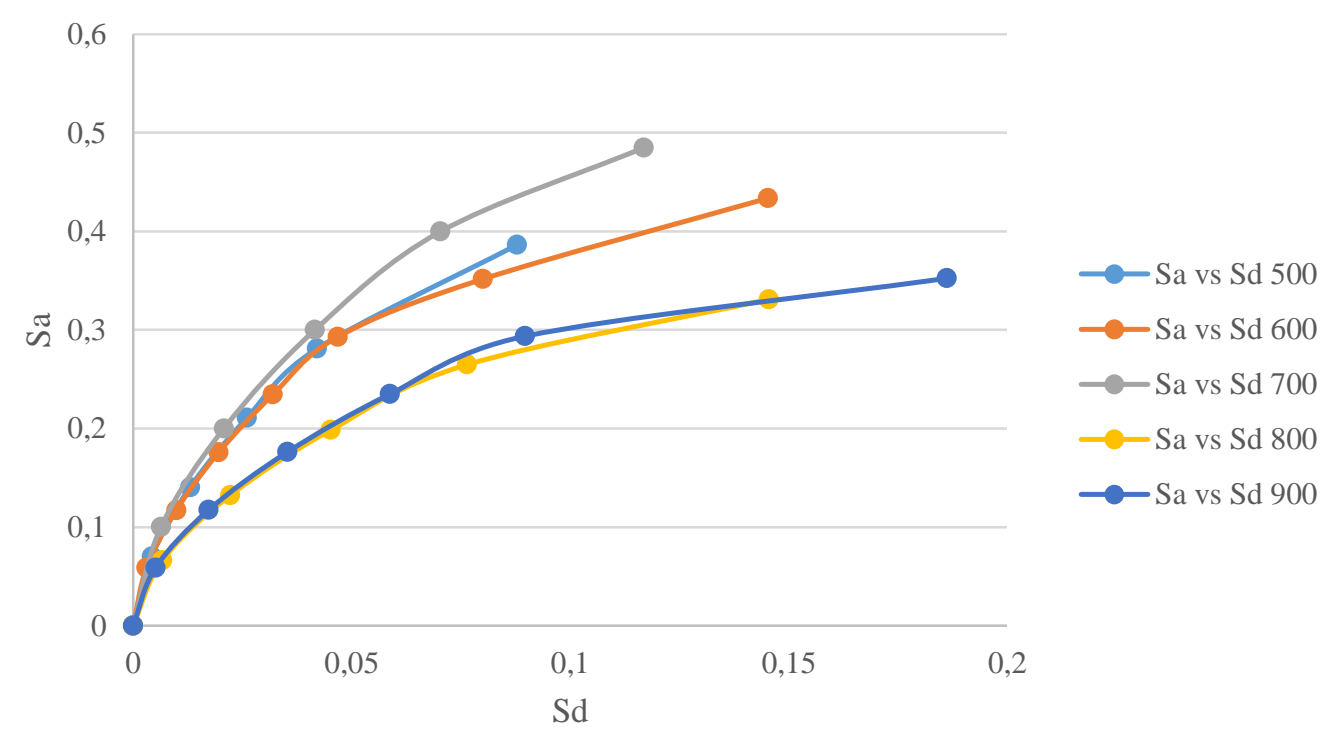

Gambar 1 Spektrum kapasitas untuk 4 tiang non elastic 


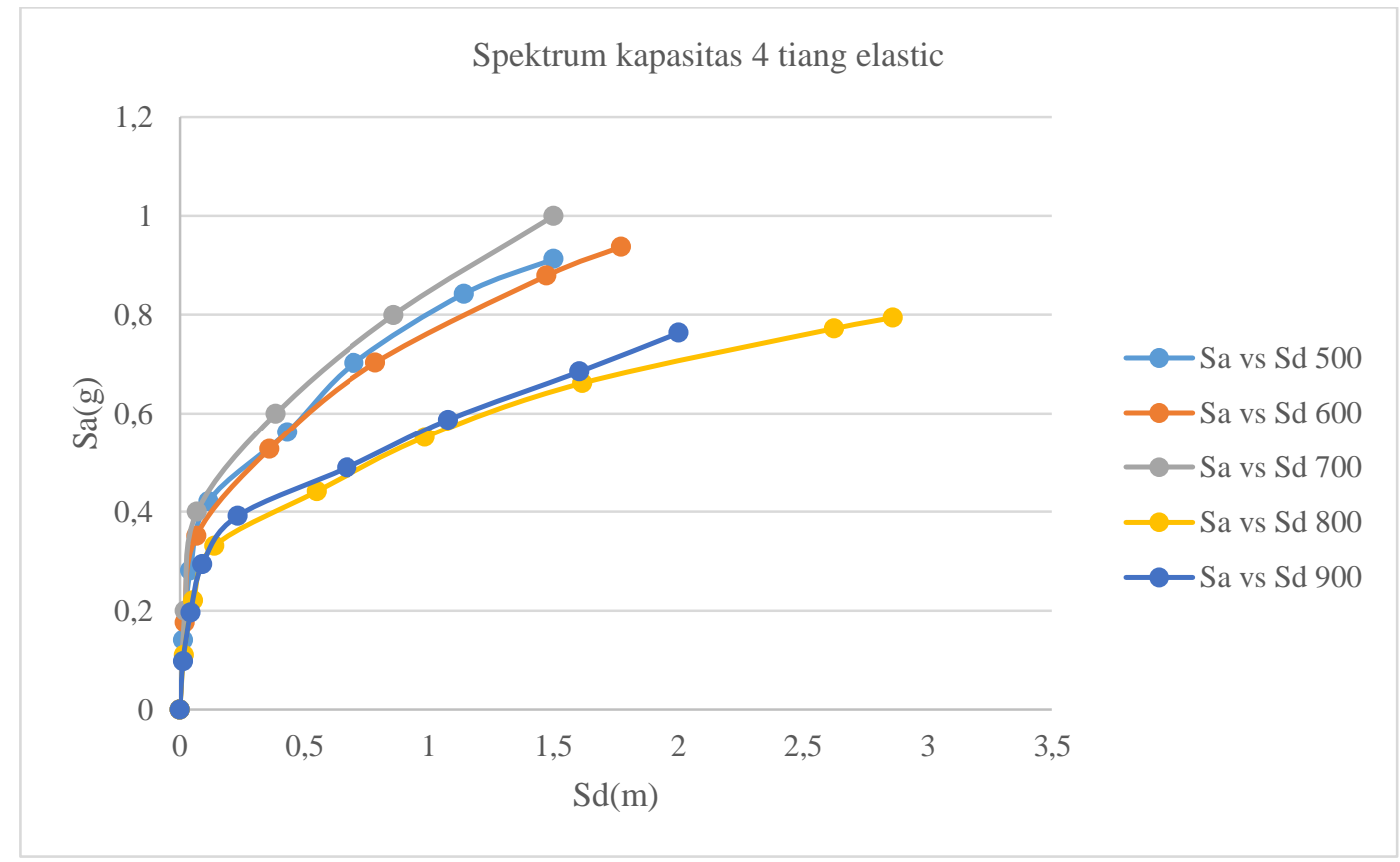

Gambar 2 Spektrum kapasitas untuk 4 tiang elastic

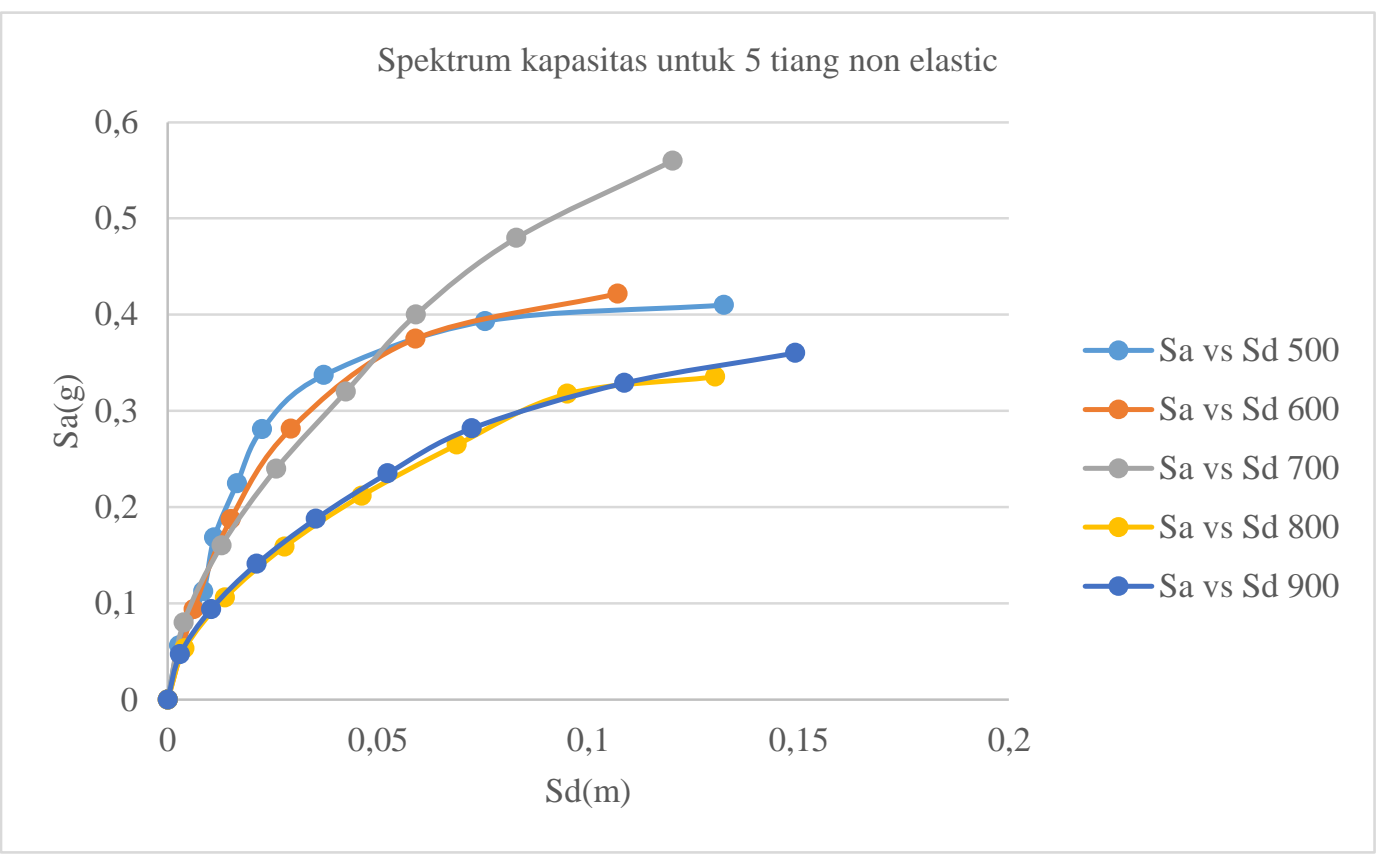

Gambar 3 Spektrum kapasitas untuk 5 tiang non elastic 


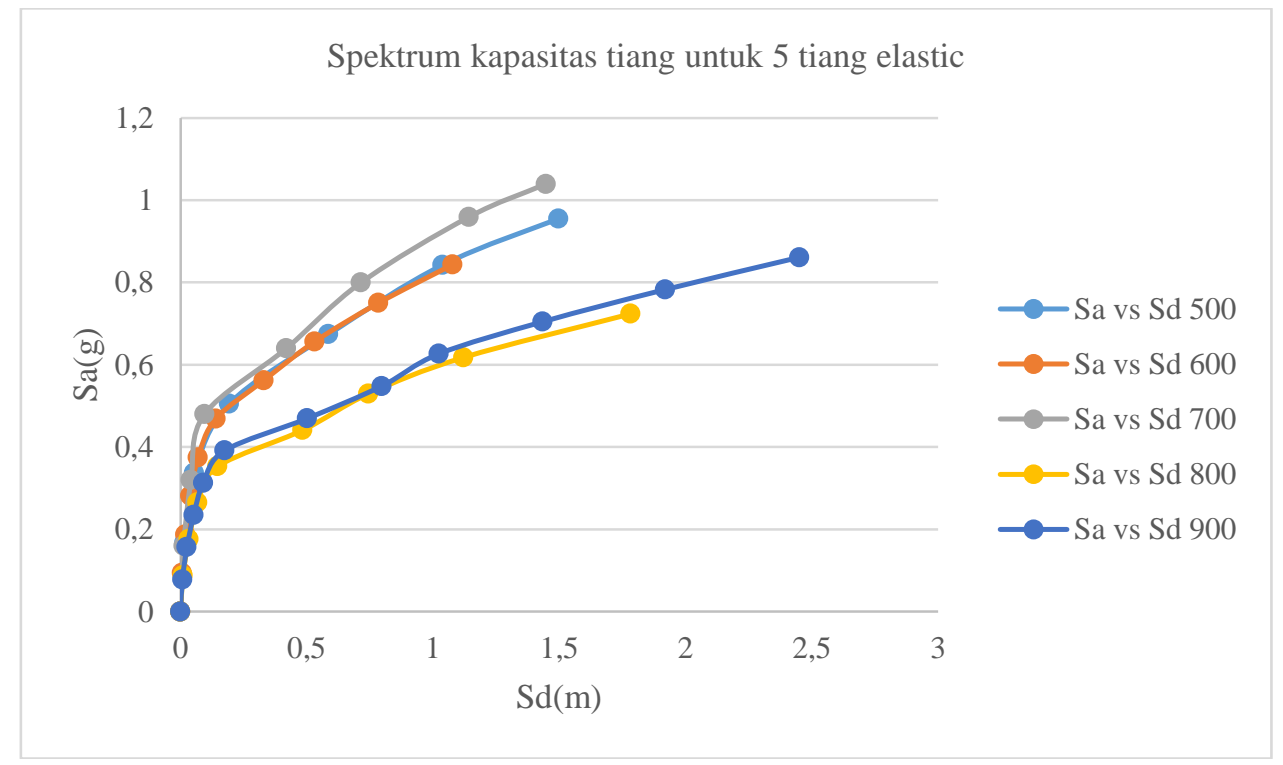

Gambar 4 Spektrum kapasitas tiang untuk 5 tiang elastic

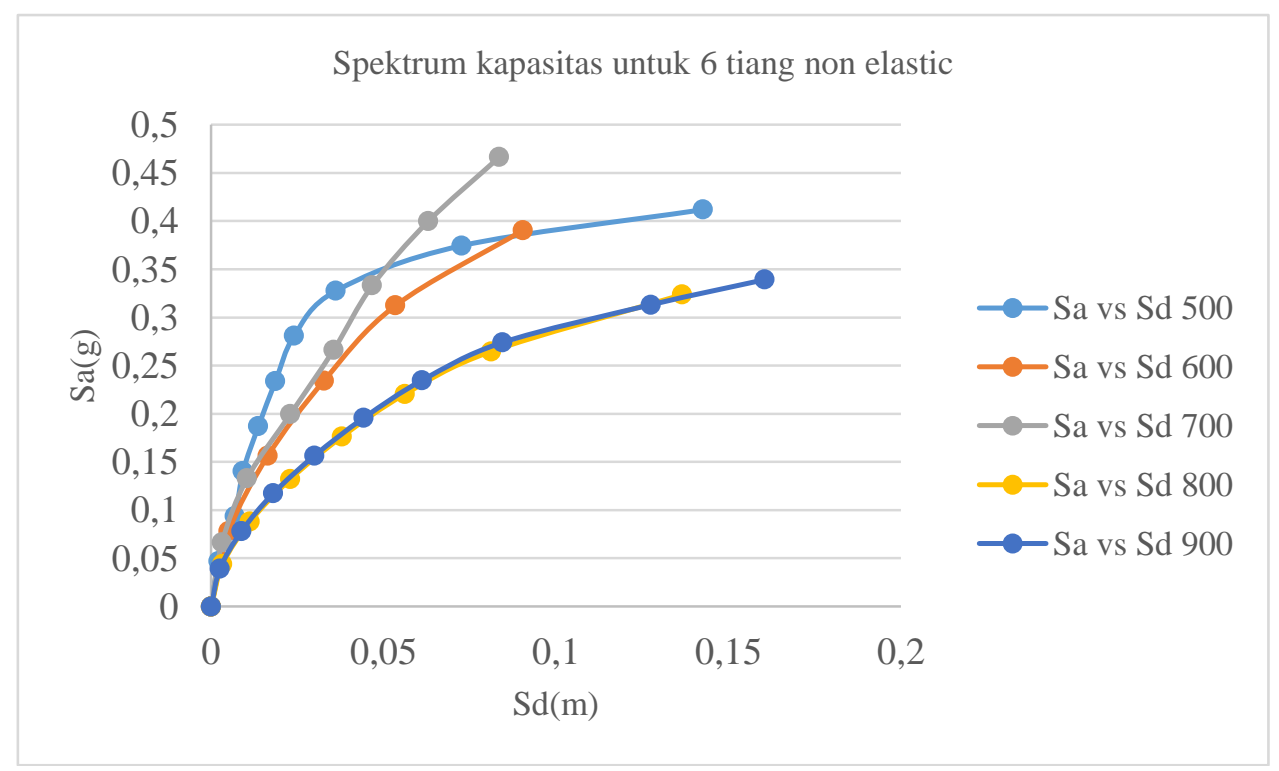

Gambar 5 Spektrum kapasitas tiang untuk 6 tiang non elastic 


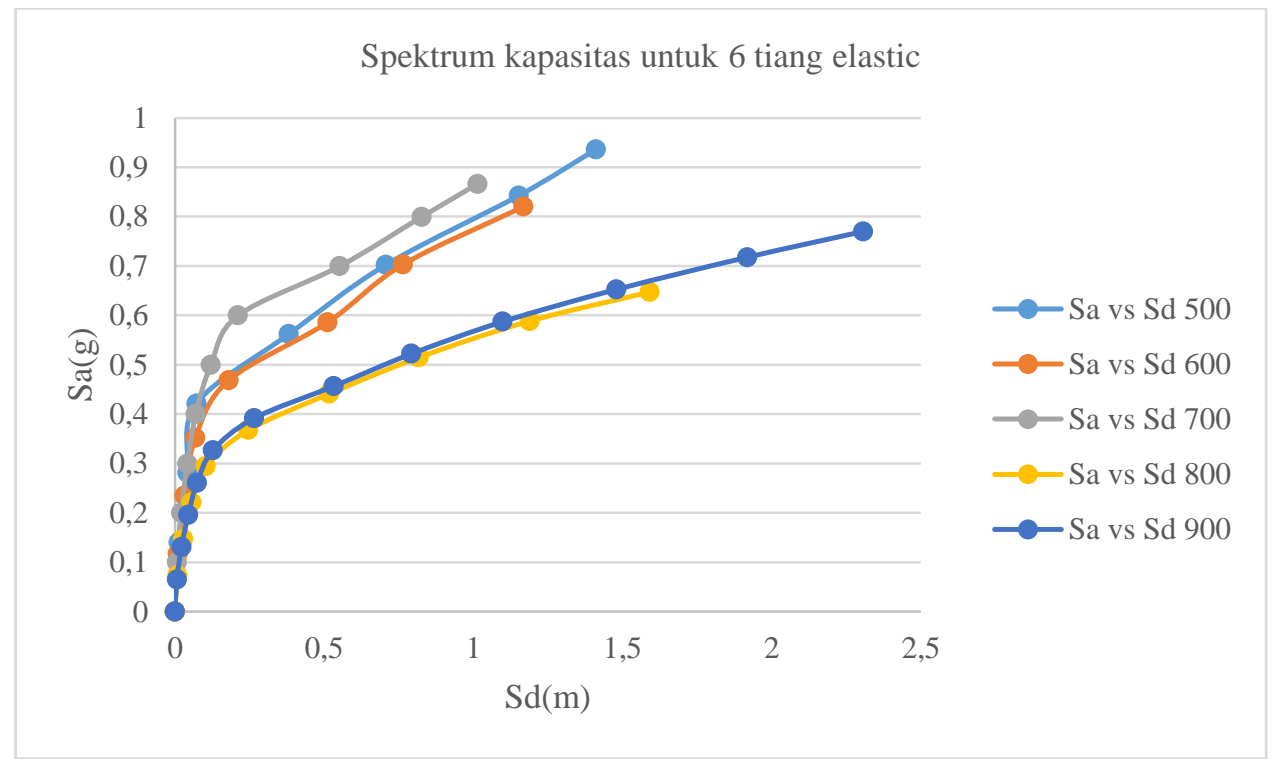

Gambar 6 Spektrum kapasitas untuk 6 tiang elastic

Dalam tabel 49.1 49.2 dan 49.3 kita dapat melihat bahwa hasil pile drift ratio yang telah dicek dengan ATC-40 adalah immediate occupancy sampai dengan damage control. Untuk pengecekan terhadap Pushover analysis of underground adalah damage control sampai dengan life safe-damage state.

Pada table 49.1,49.2 dan 49.3 kita dapat melihat perubahan yang besar terhadap beban lateral yang dapat diterima tiang elastic dan non elastic.

Pada gambar 4.67 sampai dengan gambar 4.72 kita dapat melihat Sa vs Sd yang terjadi pada diameter 500mm ke diameter $700 \mathrm{~mm}$ cenderung naik yang berarti peningkatan pada spectrum kapasitas. Pada Diameter $800 \mathrm{~mm}$ terjadi penurunan spectrum kapasitas kemudian naik lagi pada diameter $900 \mathrm{~mm}$.

\section{KESIMPULAN}

Berdasarkan hasil analisis dapat disimpulkan bahwa :

1. Perbandingan beban lateral antara tiang kelompok yang dapat diterima berdasarkan elastic dan non elastic, kelompok tiang elastic mampu menerima beban lateral lebih besar atau sama dengan $(\geq) 2 \mathrm{x}$ beban lateral tiang non elastic.

2. Berdasarkan hasil program GROUP, Displacement tertinggi yang dihasilkan tiap tiang berdasarkan kelompok tiang masing-masing dengan pembebanan lateral adalah sama.

3. Tingkat kinerja tiang kelompok yang dihasilkan dan dicek berdasarkan ATC-40 dan Pushover analysis of underground structures memenuhi syarat minimum, yaitu life safety.

4. Berdasarkan kurva spektrum kapasitas, semakin besar dimensi steel pipe maka kurva spektrum kapasitas meningkat seperti dimensi $500 \mathrm{~mm}$ sampai $700 \mathrm{~mm}$. Pada dimensi $800 \mathrm{~mm}$ terjadi penurunan kurva kapasitas karena penambahan tebal pada dimensi dan meningkat lagi di dimensi 900mm.

5. Berdasarkan hasil analisis tiang kelompok dengan berbagai jumlah dan dimensi,pile drift ratio semakin kecil apabila dimensi bertambah besar,tetapi pada dimensi $800 \mathrm{~mm}$ dan 900mm terjadi perbesaran pile drift ratio akibat adanya penambahan tebal pada dimensi tersebut.

6. Tingkat kinerja yang diperoleh berdasarkan metode spektrum kapasitas menurut ATC-40 belum tentu aman jika dibandingkan dengan peraturan dari Pushover analysis of underground structures karena drift yang diperoleh berdasarkan ATC-40 jauh lebih kecil dibandingkan dengan drift yang diperoleh berdasarkan Pushover analysis of underground structures. 


\section{DAFTAR PUSTAKA}

Bowless, J.E. (1991). Analisis dan Desain Pondasi Jilid 1 Edisi Keempat. Jakarta: Penerbit Erlangga. Bowless, J.E. (1991). Analisis dan Desain Pondasi Jilid 2 Edisi Keempat. Jakarta: Penerbit Erlangga.

Bowless, J.E. (1997). Foundation Analysis and Design Fifth Edition. New York: The McGraw-Hill Companies, Inc. Hardiyatmo, H.C. 2002. Teknik Pondasi 2, Edisi Kedua. Beta Offset. Yogyakarta

Suryono Sosrodarsono dan Kazuto Nakazawa. (2000) . Mekanika dan Teknik Pondasi, Jakarta:Pradya Paramita Sunggono, kh (1984). Teknik sipil. Bandung: Nova

Rahardjo, P.P. (2005). Manual Pondasi Tiang Edisi 3. Bandung: Publikasi GEC, Universitas Katolik Parahyangan. Reese, L.C. dan Van Impe, W.F. (2001). Single Piles and Pile Groups under Lateral Loading. London: Taylor \& Francis.

Reese,L.C. dan Matlock, H. (1956). Non Dimensional Solution for Laterally Loaded Piles with Soil Modulus Assumed Proporsional to Depth. Proc. Of The 9 th Texas Conf. On Soil Mechanics and Foundation Engineering, pp. 1-41. Austin, Texas. 
Analisis Pushover untuk Fondasi Tiang Kelompok dengan

Jimmi Lautan, et al Menggunakan Tiang Pancang Steel Pipe 